\title{
Hubungan kinerja otak dan spiritualitas manusia diukur dengan Indonesia Spiritual Health Assessment pada tokoh agama Islam di Kabupaten Bolaang Mongondow
}

\author{
${ }^{1}$ Putra Pakaya \\ ${ }^{2}$ Taufiq F. Pasiak \\ ${ }^{2}$ Sonny J. R. Kalangi \\ ${ }^{1}$ Kandidat Skripsi Fakultas Kedokteran Universitas Sam Ratulangi Manado \\ ${ }^{2}$ Bagian Anatomi-Histologi Universitas Sam Ratulangi Manado \\ Email: mpapakaya@gmail.com
}

\begin{abstract}
Human brain contains about 100 billion cells that have complex functions as the central control of all activities. The brain is an organ in which the interaction of soul and body (mind body interaction) occurs and is very influential on human spirituality. Spirituality is built by four observable aspects, as follows: spiritual experience, positive emotion, meaning of life, and ritual. Health Law of the Republic of Indonesia Number 36 Year 2009 Chapter I Article 1 Paragraph 1 defines health by integrating the spiritual aspect as part of the definition of health. Indonesia Spiritual Health Assessment (ISHA) is a neuroscience-based test that includes human spirituality profile so it can find spirituality and its relation to brain performance. This study was aimed to determine the relationship of brain performance and human spirituality among Islamic religious leaders in Bolaang Mongondow. This was an observational study with a cross sectional design. There were 57 Islamic religious leaders as respondents. Data were retrieved by distributing questionnaires ISHA to the respondents. The statistical analysis showed that the correlation between temporal lobes and spiritual experience had an $\mathrm{r}$ value $=0.304$ and $\mathrm{p}$ value $=$ 0.022. Conclusion: There was a relationship between the performance of the brain and human spirituality in particular the relationship between the temporal lobe and spiritual experience among Islamic religious leaders in Bolaang Mongondow
\end{abstract}

Keywords: brain performance, spirituality

\begin{abstract}
Abstrak: Otak manusia berisi sekitar 100 miliar sel yang memiliki fungsi kompleks sebagai pusat pengendali seluruh aktivitas manusia. Otak merupakan organ tubuh dimana terjadinya interaksi 'jiwa' dan 'badan' (mind body interaction) yang sangat berpengaruh terhadap spiritualitas manusia. Spiritualitas dibangun oleh empat aspek yang dapat diamati yaitu pengalaman spiritual, emosi positif, makna hidup, dan ritual. Undang-Undang Kesehatan Republik Indonesia Nomor 36 Tahun 2009 Bab I Pasal 1 ayat 1mendefinisikan kesehatan, yaitu dengan memasukkan aspek spiritual sebagai bagian dari batasan sehat. Indonesia Spiritual Health Assessment (ISHA) merupakan uji berbasis neurosains yang memuat tentang profil spiritualitas manusia sehingga dapat mengetahui spiritualitas dan kaitannya dengan kinerja otak. Penelitian ini bertujuan untuk mengetahui hubungan kinerja otak dengan spiritualitas manusia pada tokoh agama Islam di Kabupaten Bolaang Mongondow. Jenis penelitian ialah observasional dengan desain potong lintang. Terdapat 57 orang tokoh agama Islam di Kabupaten Bolaang Mongondow sebagai responden. Data diambil dengan cara membagikan kuisioner ISHA kepada responden. Hasil analisis statistik menunjukkan korelasi antara lobus temporalis dengan pengalaman spiritual $(\mathrm{r}=0,304 ; \mathrm{p}=0,022)$. Simpulan: Pada tokoh agama Islam di Kabupaten Bolaang Mongondow terdapat hubungan antara kinerja otak dengan spiritualitas manusia khususnya hubungan one to one antara lobus temporalis dan pengalaman spiritual.
\end{abstract}

Kata kunci: kinerja otak, spiritualitas 
Manusia adalah makhluk hidup yang selalu berpikir dengan otak sepanjang hayatnya. ${ }^{1}$ Otak manusia berisi sekitar 100 miliar sel yang memiliki fungsi kompleks sebagai pusat pengendali seluruh aktivitas manusia dengan berat kurang lebih 1400 gram atau kira-kira $2 \%$ dari berat badan. Otak berperan paling penting dibandingkan bagian-bagian tubuh lainnya dan merupakan organ tubuh dimana terjadinya interaksi 'jiwa' dan 'badan' (mind body interaction $)^{2-4}$

Dengan menggunakan alat kedokteran nuklir Single-photon Emission Computed Tomography (SPECT) yang dapat melihat struktur otak secara global dan terperinci juga dapat melihat aktivitas otak secara langsung, Amen membagi otak ke dalam 5 sistem utama, yaitu: cortex prefrontalis, sistem limbik, ganglia basalis, gyrus cingulatus, dan lobus temporalis. ${ }^{5}$

Menurut Newberg dan D'Aquili, kegiatan spiritual dalam otak manusia diselenggarakan oleh sejumlah komponen otak yang secara bersama-sama disebut operator kognitif. Dalam bukunya Tuhan dalam Otak Manusia (2012), Pasiak memperkenalkan istilah Operator Neurospiritual (ONS) yang merupakan kombinasi operator kognitif dari Newberg dengan fungsi cortex prefontalis (CFP) yang menghasilkan makna hidup. ${ }^{5}$ Sebuah operator neurospiritual disusun oleh: 1) Cortex prefontalis, berfungsi sebagai supervisor (pengawas). Bagian ini bertanggung jawab dalam membuat keputusan (baik atau buruk), merencanakan masa depan (future planning), dan membuat penilaian (judgement); 2) Sistem limbik, berperan dalam pusat pengaturan suasana hati. Bagian otak ini juga berperan dalam pusat emosi dimana bagian ini berfungsi sebagai pengatur emosi manusia dan memori emosi; 3) Gyrus cingulatus, berperan dalam memindahkan perhatian dari satu objek ke objek yang lain; 4) Ganglia basalis, berfungsi dalam mengatur kecepatan siaga tubuh (body's idling speed). Jika bagian ini terlalu aktif maka akan menimbulkan kecemasan, kepanikan, ketakutan, dan sikap menjauhi masalah yang dihadapi; 5) Lobus temporalis, berperan dalam pengingatan, bahasa, facial recognition, dan pengendalian amarah; dan 6) Sistem saraf otonom merupakan bagian dari sistem saraf motorik yang berdifat otonom (independen). Aktivasi dari sistem saraf otonom pada prinsipnya terjadi di hipotalamus, batang otak, dan spinalis. Impulsnya akan diteruskan melalui sistem simpatis dan parasimpatis. ${ }^{5-7}$

Berdasarkan

Undang-Undang Kesehatan Republik Indonesia Nomor 36 Tahun 2009 Bab I Pasal 1 ayat 1, kesehatan adalah keadaan sehat, baik secara fisik, mental, spiritual maupun sosial yang memungkin-kan setiap orang untuk hidup produktif secara sosial dan ekonomis. ${ }^{8}$ Jika dibandingkan dengan definisi kesehatan menurut Undang-undang Kesehatan Republik Indonesia Nomor 23 Tahun 1992 yaitu kesehatan sebagai keadaan sejahtera dari badan, jiwa, dan sosial yang memungkinkan setiap orang hidup produktif secara sosial dan ekonomis. Dalam rentang waktu 17 tahun terdapat perubahan pemikiran dalam mendefinisikan kesehatan, yaitu dengan memasukkan aspek spiritual sebagai bagian dari batasan sehat. $^{4}$

Spiritualitas adalah kebutuhan tertinggi manusia yang merupakan dasar bagi tumbuhnya harga diri, nilai-nilai, moral, dan rasa memiliki. Spiritualitas lebih melihat aspek yang ada di dalam lubuk hati, riak getaran hati nurani pribadi, dan cita rasa total dari pribadi seseorang. ${ }^{5,9}$ Spiritualitas mempunyai empat dimensi yaitu: makna hidup, emosi positif, pengalaman spiritual, dan ritual. Makna hidup merupakan suatu manifestasi spiritualitas berupa penghayatan intrapersonal yang bersifat unik, ditunjukkan dalam hubungan bersosial (interpersonal) yang bermanfaat, menginspirasi dan dapat mewariskan sesuatu yang memiliki nilai bagi kehidupan manusia. Emosi positif merupakan manifestasi spiritualitas berupa kemampuan mengelola pikiran dan perasaan dalam hubungan intrapersonal sehingga seseorang memiliki nilai-nilai kehidupan yang mendasari 
kemampuan bersikap dengan tepat. Pengalaman spiritual merupakan manifestasi spiritual di dalam diri seseorang berupa pengalaman spesifik unik terkait hubungan dirinya dengan Tuhan dalam berbagai tingkatannya. Ritual merupakan manifestasi spiritualitas berupa tindakan terstruktur, sistematis, berulang, melibatkan aspek motorik, kognisi, dan afeksi yang dilakukan menutur suatu tata cara tertentu baik individual maupun komunal. $^{5}$

\section{METODE PENELITIAN}

Jenis penelitian ini ialah observasional dengan desain potong lintang. Penelitian ini dilaksanakan di Kabupaten Bolaang Mongondow, Provinsi Sulawesi Utara pada bulan November-Desember 2016. Jumlah responden yang diambil pada penelitian ini berjumlah 57 orang. Data diambil dengan cara membagikan kuisioner Indonesia Spiritual Health Assessment (ISHA) kepada responden. Data an dianalisis menggunakan korelasi Spearman, karena kedua variabel merupakan variabel kategorik yang berbentuk skala ordinal.

\section{HASIL PENELITIAN DAN BAHASAN}

Responden yang ikut dalam penelitian ini ialah para Imam Masjid yang ada di Kabupaten Bolaang Mongondow. Karakteristik responden untuk distribusi frekuensi usia dan tingkat pendidikan dapat dilihat pada Tabel 1 dan Tabel 2.

Hasil dari ISHA yang dibagikan kepada responden dapat dilihat pada Gambar 1 mengenai spiritualitas dan Gambar 2 mengenai dominasi otak. Pada hasil tersebut memuat empat dimensi dari spiritualitas dan rata-rata hasil yang didapatkan ialah excellent (Gambar 1). Untuk hasil dominasi otak didapatkan nilai tersebar antara excellent dan moderate (Gambar 2).

Hasil perhitungan korelasi pada SPSS statistics version 24 antara kinerja otak dan spiritualitas dalam hal ini lobus temporalis dan pengalaman spiritual (Tabel 3).

Tabel 1. Distribusi usia responden

\begin{tabular}{cc}
\hline Usia (tahun) & Frekuensi \\
\hline $46-50$ & 10 \\
$51-55$ & 16 \\
$56-60$ & 12 \\
$>60$ & 19 \\
Total & 57 \\
\hline
\end{tabular}

Tabel 2.Distribusi pendidikan responden

\begin{tabular}{cc}
\hline Jenjang pendidikan & Frekuensi \\
\hline Tamat SD & 30 \\
Tamat SMP & 13 \\
Tamat SMA & 10 \\
Diploma/Perguruan & 4 \\
Tinggi & \\
Total & 57 \\
\hline
\end{tabular}

\section{KOMPONEN SPIRITUALITAS}

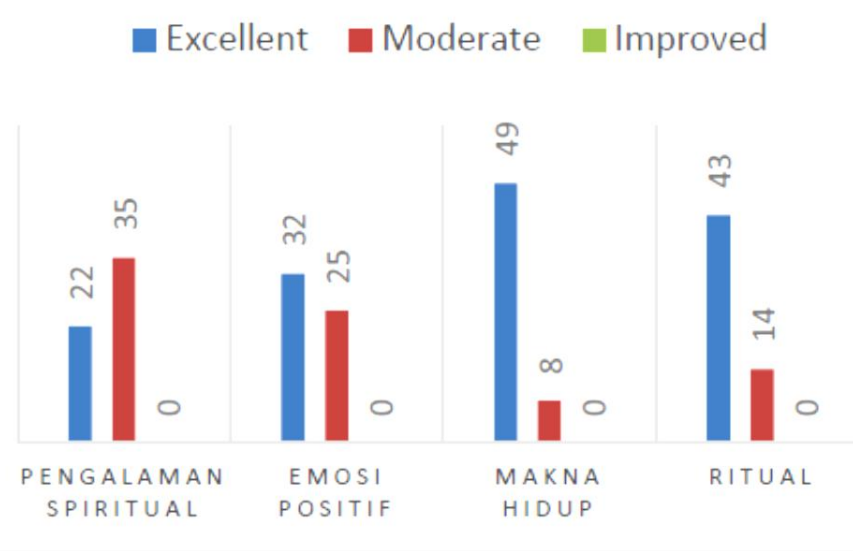

Gambar 1. Hasil ISHA spiritualitas responden 


\section{KOMPONEN KINERJA OTAK}

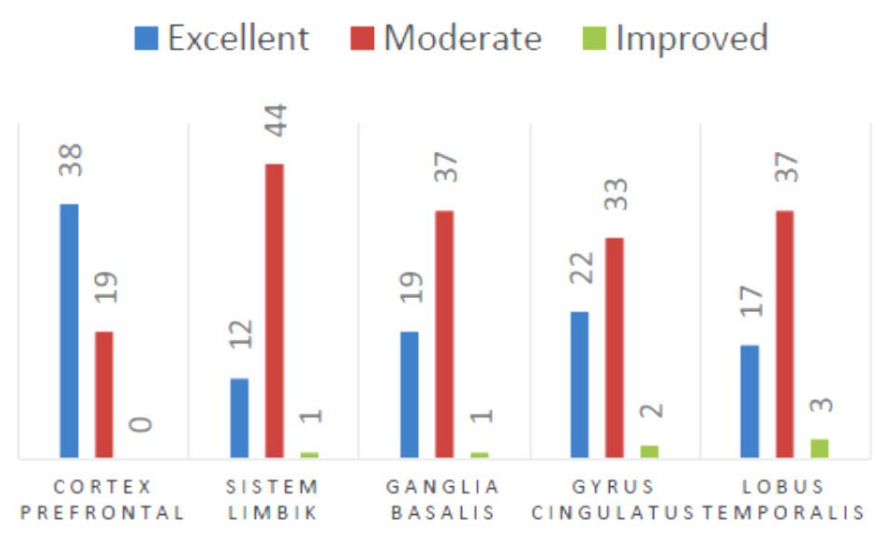

Gambar 2. Hasil ISHA kinerja otak responden

Tabel 3. Hasil analisis lobus prefrontalis dan pengalaman spiritual.

\begin{tabular}{lccc}
\hline \multicolumn{1}{c}{ Spearman's Rho } & & Lobus temporalis & Pengalaman spiritual \\
\hline Lobus Temporalis & r & 1.000 & $0.304^{*}$ \\
& p &. & 0.022 \\
& $\mathrm{~N}$ & 57 & 57 \\
\hline Pengalaman Spiritual & $\mathrm{r}$ & $0.304^{*}$ & 1.000 \\
& $\mathrm{p}$ & 0.022 &. \\
& $\mathrm{~N}$ & 57 & 57 \\
\hline
\end{tabular}

Menurut Calton, kekuatan hubungan dua variabel secara kualitatif dapat dibagi dalam 4 tingkatan, yaitu: ${ }^{10}$ 1) $\mathrm{r}=0,00-0,25$ $=$ tidak ada hubungan/hubungan lemah; 2) $\mathrm{r}$ $=0,26-0,50$ =hubungan sedang; 3$) \mathrm{r}=0,51$ 0,75 =hubungan kuat; 4) $\mathrm{r}=0,76-1,00$ =hubungan sangat kuat/sempurna.

Hasil analisis menunjukkan korelasi antara lobus temporalis dengan pengalaman spiritual memiliki nilai $\mathrm{r}=$ 0,304 dan nilai $\mathrm{p}=0,022$ yang menunjukkan bahwa terdapat hubungan one to one yang sedang dan berpola positif antara lobus temporalis dengan pengalaman spiritual. Artinya semakin baik kinerja lobus temporalis maka akan menghasilkan pengalaman spiritual yang lebih baik.

Pengalaman spiritual merupakan suatu perwujudan spiritualitas di dalam diri seseorang berupa pengalaman spesifik dan unik terkait hubungan dirinya dengan
Tuhan dalam berbagai tingkatannya. ${ }^{5}$ Menurut Maslow (1964), pengalaman spiritual adalah peak experience, plateauthe farthest reaches of human nature. Pengalaman spiritual merupakan puncak tertinggi yang dapat dicapai oleh manusia serta merupakan peneguhan dari keberadaannya sebagai makhluk spiritual. ${ }^{11}$

Underwood dan Teresi (2002), menyatakan bahwa pengalaman spiritual merupakan presepsi tentang adanya sesuatu yang bersifat transenden atau luar biasa dalam kehidupan sehari-hari dan presepsi tentang keterlibatan dengan peristiwaperistiwa transenden dalam kehidupan sehari-hari. $^{12}$

Spiritualitas tidak berdiri sendiri pada dirinya, akan tetapi merupakan suatu hal yang dialami. Pengalaman yang dialami inilah yang disebut dengan pengalaman spiritual. Pengalaman spiritual dalam paradigma manusia banyak dihubungkan 
dengan hal-hal gaib. Sebenarnya pengalaman spiritual sendiri merupakan pemaknaan dari sesuatu yang dialami. ${ }^{11}$

Underwood (2006) menyatakan bahwa pengalaman spiritualitas sehari-hari meliputi rasa kagum, rasa syukur, kasih sayang, menyadari kasih sayang, keinginan untuk lebih dekat dengan Tuhan. ${ }^{12}$ Orang bias saja mengalami pengalaman yang biasa, misalnya dinasehati oleh seorang pengemis, tapi orang tersebut memaknai kejadian tersebut sebagai hal yang luar biasa dan mengilhami dia untuk berpikir, merasakan dan melakukan sesuatu. Hal ini yang disebut sebagai pengalaman spiritual. $^{11}$

Lobus temporalis terletak di belakang mata dan berperan dalam pengingatan, bahasa, facial recognition, dan pengendalian amarah. Bila bagian ini rusak, terutama lobus temporalis kiri, seseorang menjadi mudah marah, sulit mengingat dan belajar, dan suasana hati (mood) berubahubah dengan cepat. Jika bagian ini bekerja dengan baik maka akan menghasilkan kedamaian batin (inner peace). ${ }^{5}$

Dari bahasan di atas maka dapat dijelaskan bahwa terdapat hubungan antara lobus temporalis dengan pengalaman spiritual. Jika kinerja otak dalam hal ini bagian lobus temporalis seseorang berkerja dengan baik maka akan menghasilkan kesehatan spiritualitas yang baik dalam hal pemahaman seseorang sebagai makhluk spiritual, yang mengembalikan seseorang kepada diri yang sebenarnya dan pemaknaan atas sesuatu yang bersifat transenden dalam kehidupannya.

\section{SIMPULAN}

Dari hasil penelitian dapat disimpulkan bahwa terdapat hubungan antara kinerja otak dan spiritualitas manusia pada tokoh agama Islam di Kabupaten Bolaang Mongondow, khususnya terdapat hubungan one to one antara lobus temporalis dengan pengalaman spiritual.

\section{SARAN}

Perlu dilakukan penelitian lebih lanjut dengan jumlah sampel yang lebih besar, penjelasan, dan pengawasan pada saat pengisian kuisioner serta memperhatikan umur dan tingkat pendidikan responden untuk memperkuat nilai akurasi dari hasil penelitian ini.

\section{UCAPAN TERIMA KASIH}

Ucapan terima kasih ditujukan kepada dr. DjonWongkar, M.Kes, AIFO, dr. Shane H. R. Ticoalu, M.Kes, AIFO, serta seluruh pihak yang secara langsung maupun tidak langsung telah memberikan ide dan gagasan pada penulis.

\section{DAFTAR PUSTAKA}

1. Mandar. Peranan cognitive neuroscience dalam dunia pendidikan. In: Prosiding Seminar Nasional Penelitian dan PKM Sains, Teknologi, dan Kesehatan, 2011.

2. Wulandari IP. Pembuatan alat ukur kecepatan respon manusia berbasis mikrokrontoller at 8958252 . Neutino. 2009;1:208.

3. Kushartanti W. Gerak 7'(tujuh menit) yang mencerdaskan. [cited 2016 September 12]. Available from: http://staff.uny.ac.id

4. Pasiak T. Kesehatan Spiritual dan Kesehatan Otak. Unpublished [cited 2016 Oktober 10]. Available from http://taufiqpasiak.com/kesehatanspiritual-dan-kesehatan-otak/

5. Pasiak T. Tuhan dalam otak manusia: mewujudkan kesehatan spiritual berdasarkan neurosains (1st ed). Bandung: PT Mizan Pustaka, 2012; p. 42-3,194-5.

6. Liza. Otak manusia, neurotransmiter, dan stres [cited 2016 Oktober 9]. Available from: https://adiwarsito. files.wordpress.com/

7. Indra A. Aktivitas otonom [cited 2016 September 12]. Available from: http://jurnal.unsyiah.ac.id

8. Undang-undang Republik Indonesia No. 36 Tahun 2009 Tentang Kesehatan, Bab I Pasal 1

9. Hudori. Relasi kecerdasan spiritual dan pencarian jejak Tuhan [cited 2016 September 12]. Available from: http://ejournal-unisma.net

10. Santoso I. Manajemen Data: untuk analisis data penelitian kesehatan (1st ed). 
Pakaya, Pasiak, Kalangi: Hubungan kinerja otak dan spiritualitas ...

Yogyakarta: Gosyen Publishing, 2013; p. 88-9.

11. Cahyono R. Dinamika emosi dan pengalaman spiritual beragama: studi kasus kualitatif pengalaman perubahan keyakinan beragama [cited 2016 September 9]. Available from: http://journal.unair.ac.id
12. Liwarti. Hubungan pengalaman spiritual dengan psychological well being pada penghuni lembaga pemasyarakatan [cited 7 Desember 2016]. Available from

http://ejournal.umm.ac.id/index.php/j spp/article/view/1350/1445 